\title{
Watering Station Best Management Practices for Container Nurseries ${ }^{1}$
}

\author{
Tom Yeager ${ }^{2}$
}

\section{Background of the Best Management Practices (BMPs) Program}

The Florida Watershed Restoration Act of 1999 (Olexa et al. 2017) established the provision for BMPs to be voluntarily implemented by producers of agricultural commodities, including nursery crops. Producers commit to implement BMPs specific to their operation by signing a Notice of Intent (NOI) that is filed with the Florida Department of Agriculture and Consumer Services' (FDACS) Office of Agricultural Water Policy (OAWP). Once the BMPs are implemented, the producer's impact on ground- and surface-water quality is presumed to meet water-quality standards for the state. The OAWP and Florida Department of Environmental Protection ensure that BMPs fulfill their intent.

Management of runoff from a watering station is a new BMP in the 2014 edition of the manual titled Water Quality/Quantity Best Management Practices for Florida Nurseries. Watering stations are specialized irrigation structures where plants are watered immediately after transplanting. Plant-bearing containers are transported on wagons to a watering station, where irrigation water is applied rapidly with high-volume, shower-like nozzles that are elevated above closely spaced plants. Plants are often passed through the water station several times to apply enough water to "settle" the substrate around roots and ensure that the substrate achieves maximum water-holding capacity. Water not retained by the container substrate (leachate), in addition to water falling between containers, becomes runoff.

The new BMP was necessary because a large volume of shower water can leach soluble nutrients, such as nitrogen and phosphorus, from fertilized substrate (Yeager et al. 2018), as well as displace fertilizer particles from containers. Runoff can be laden with particulates and nutrients, and the intent of the new BMP is to provide a way to mitigate runoff to minimize the environmental impact on natural waters. Detention of runoff in a pond (Cooper and Knight 1990) or basin (Edwards et al. 1999) is an effective way to trap sediment and nutrients, such as nitrogen and phosphorus, that would otherwise impact natural waters.

The new BMP specifically states that "if your container operation has a watering station used to irrigate plants immediately after potting, collect runoff in a small basin, direct the runoff to an existing basin, or route runoff through an onsite vegetative treatment area." The purpose of this fact sheet is to provide examples of how runoff from watering stations at two nurseries was managed after implementation of the BMP.

\section{Runoff Management Methods}

Several methods for managing particulates and nutrients in runoff water leaving nursery production areas have been investigated. These methods often involve some type of water

1. This document is ENH1326, one of a series of the Environmental Horticulture Department, UF/IFAS Extension. Original publication date October 2020. Visit the EDIS website at https://edis.ifas.ufl.edu for the currently supported version of this publication.

2. Tom Yeager, professor, Environmental Horticulture Department, UF/IFAS Extension, Gainesville, FL 32611.

The Institute of Food and Agricultural Sciences (IFAS) is an Equal Opportunity Institution authorized to provide research, educational information and other services

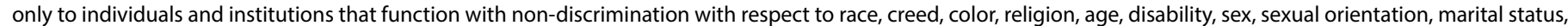

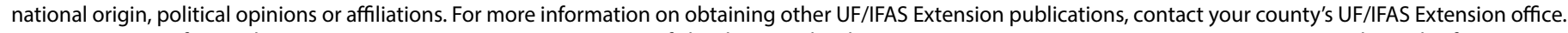
U.S. Department of Agriculture, UF/IFAS Extension Service, University of Florida, IFAS, Florida A \& M University Cooperative Extension Program, and Boards of County Commissioners Cooperating. Nick T. Place, dean for UF/IFAS Extension. 
detention that slows the velocity of runoff water discharge. Detention is usually accomplished by a topography change, such as a swale or constructed wetland (Taylor et al. 2006). Another common method is to collect runoff water in a basin (Mangiafico et al. 2008). While the primary function of a basin can be water storage, a reduction in environmental impact can also occur as the movement of runoff water in the basin slows and suspended particles and associated nutrients settle. Basin size should vary depending on runoff volume. A basin constructed for water storage and reuse is usually larger than a basin constructed to detain water for a short time.

\section{Runoff Management for Watering Stations}

Two nursery sites were selected to demonstrate how to manage runoff from watering stations. Each site required different methods due to how the runoff drained from each watering station.

At the first site (Figure 1), the runoff was conveyed from the watering station by an open $10 \mathrm{ft}$ wide ditch with abruptly sloped sides that also received drainage from a small area of plant production. These features allowed for the installation of a retention structure anchored with concrete pillars on each side of the ditch. Pillars were fitted vertically with a metal channel to hold ends of wooden boards that spanned the ditch. The boards retained runoff and slowed the flow of suspended particulates to promote settling. Maximum depth of retained runoff water was approximately 21 inches near the boards. The actual depth was limited by the volume of runoff. While runoff from the watering station was retained by the boards (Figure 1), runoff from storm events traversed the top of boards. To contain the runoff, a basin was constructed downstream (Figure 2).

At a second nursery site (Figure 3), a new watering station was installed to collect and transport runoff to a grassed area. The sloped grassed area receiving runoff was approximately $10 \mathrm{ft}$ wide by $400 \mathrm{ft}$ long and located between plant production beds that were approximately $80 \mathrm{ft}$ down grade from the watering station. A slightly sloped concrete pad was constructed under the shower, and all the runoff flowed to a drainage channel located on one side of the pad. The channel slope directed runoff to a pipe that transported runoff to the grassed area, where the vegetation could filter or remove sediment and nutrients transported by runoff (Lee et al. 2003).

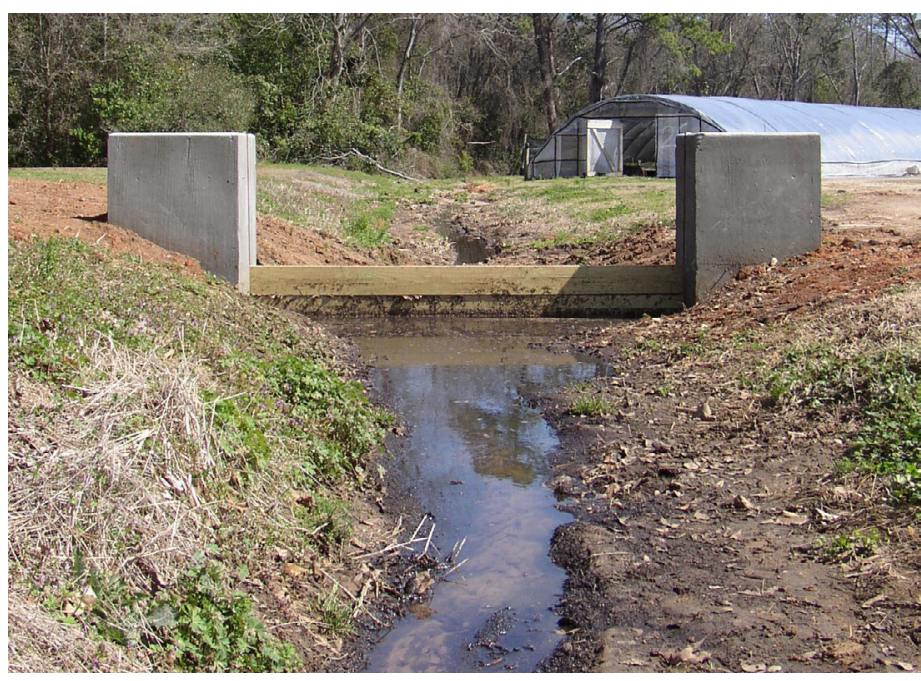

Figure 1. Wooden boards installed for management of runoff from watering station located upstream.

Credits: T. Yeager, UF/IFAS

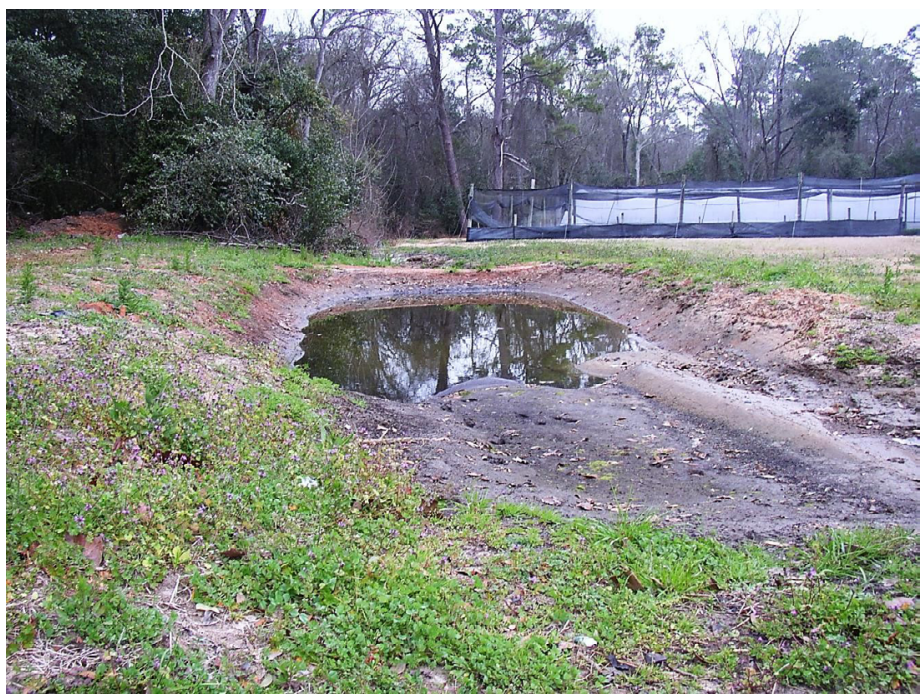

Figure 2. Basin installed downstream from wooden boards. Credits: T. Yeager, UF/IFAS

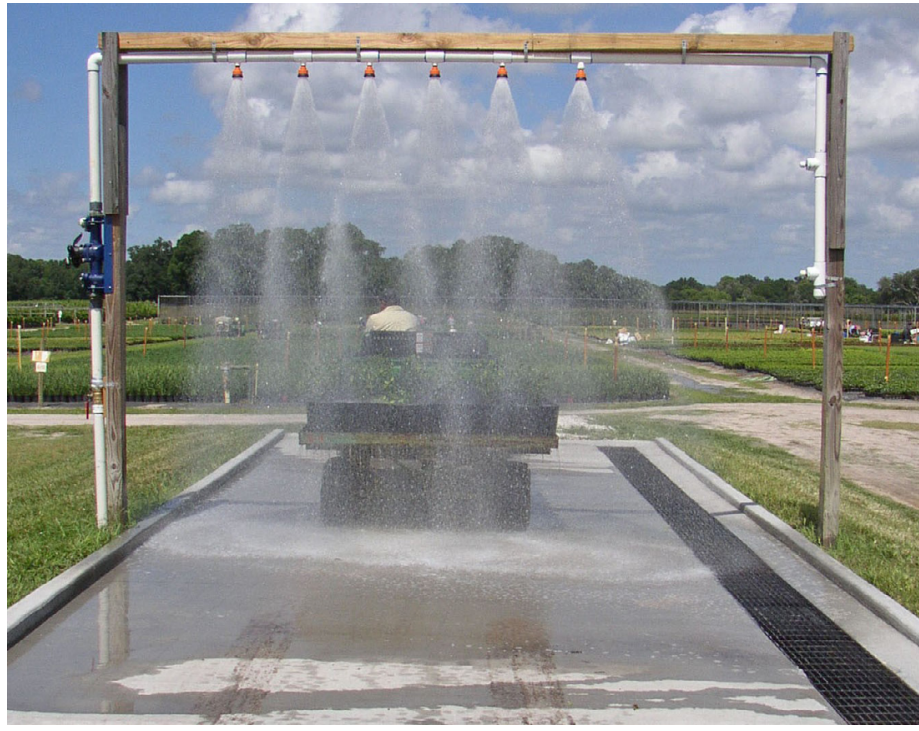

Figure 3. Concrete pad installed for runoff management at the watering station.

Credits: T. Yeager, UF/IFAS 


\section{Summary}

The two examples show how runoff from watering stations was managed according to Water Quality/Quantity Best Management Practices for Florida Nurseries. Other methods of runoff management that enhance runoff quality could be used. Assistance determining the most appropriate method of runoff management can be obtained from OAWP field staff or UF/IFAS Extension personnel. For a list of OAWP field staff, visit https://freshfromflorida.com, and visit http://solutionsforyourlife.ufl.edu/ for a list of UF/IFAS Extension personnel in your county.

\section{References}

Cooper, C. M., and S. S. Knight. 1990. "Nutrient Trapping Efficiency of a Small Sediment Detention Reservoir." Agricultural Water Management 18 (2): 149-158.

Edwards, C. L., R. D. Shannon, and A. R. Jarrett. 1999. "Sedimentation Basin Retention Efficiencies for Sediment, Nitrogen, and Phosphorus from Simulated Agricultural Runoff." Trans. ASAE 42 (2): 403-409.

Lee, K. H., T. M. Isenhart, and R. C. Schultz. 2003. "Sediment and Nutrient Removal in an Established Multi-species Riparian Buffer." J. Soil Water Conservation 58 (1): 1-8.

Mangiafico, S. S., J. Gan, L. Wu, J. Lu, J. P. Newman, B. Faber, D. J. Merhaut, and R. Evans. 2008. "Detention and Recycling Basins for Managing Nutrient and Pesticide Runoff from Nurseries." HortScience 43 (2): 393-398.

Olexa, M. T., T. Borisova, and J. Davis. 2017. Handbook of Florida Water Regulation: Florida Watershed Restoration Act. FE608. Gainesville: University of Florida Institute of Food and Agricultural Sciences. https://edis.ifas.ufl.edu/ fe608

Taylor, M. D., S. A. White, S. L. Chandler, S. J. Klaine, and T. Whitwell. 2006. "Nutrient Management of Nursery Runoff Water Using Constructed Wetland Systems." HortTechnology 16 (4): 610-614.

Yeager, T., T. Gardner, and K. Nyhuis. 2018. "Nutrient Loading from Initial Watering of Container Plants.” Acta. Hortic. 1191:183-186.

\section{Acknowledgment}

Financial support was provided by the Florida Department of Agriculture and Consumer Services (FDACS) Office of Agricultural Water Policy (OAWP). 